\title{
THE VALUE OF A HOME tREATMENT PROGRAMME FOR PAEDIATRIC PATIENTS WITH RESPIRATORY DISORDERS
}

\author{
L. SCHEEPERS, A. KNOETZE, V. M. PIETERSE*
}

\section{SUMMARY}

To establish the efficacy of a home treatment programme, two groups of short-term patients, aged I month-11 years, hospitalised for complications of respiratory disorders or chronic respiratory disorders, were studied. Both groups received intensive physiotherapy during hospitalisation, but only in the experimental group were parents counselled and a home treatment programme taught. On comparing readmission figures for the experimental and conlrol groups, there was a statistically significant difference at both $5 \%$ and $1 \%$ levels, using the chi-square test.

\section{INTRODUCTION}

"In the case of the child with chronic resporatory illness it is essential that parents be taught techniques for draining and aerating the lungs and clearing the upper respiratory tract, so that treatment commenced and supervised by the physiotherapist continues regularly at home. The teaching of parents is often difficult and time-consuming, but without their well-trained help no regime of treatment will be successful." (Shepherd, 1974).

Teaching the parent an effective home treatment programme is very time-consuming and is therefore usually neglected. In this paper we have described a project which was carried out to determine the value of such a programme to the patient, to his parents and to the hospital staff.

Respiratory disorders are some of the commonest causes of death in the infant and young child. These disorders result from varying causes, viz. infection, congenital abnormalities and genetically determined diseases.

This project, however, concentrates on the disorders which would possibly have been prevented if proper and effective treatment had been executed, i.e. bronchiolitis, broncho-pneumonia, bronchitis and asthma.

The primary problem may exist in the upper respiratory tract with infection spreading from a chronic

* B.Sc. Physiotherapy student project 1978.

University of Stellenbosch, P.O. Box 63, Tygerberg 7505.

Received 16 July 1980.

\section{OPSOMMING}

Om die doelmatigheid van 'n tuisbehandelingsprogram vas te stel, is twee groepe korttermyn pasiente, ouderdom 1 maand-11 jaar, wat gehospitaliseer is vir komplikasies van respiratoriese siektes of kroniese respiratoriese siektes, bestudeer. Beide groepe het intensiewe fisioterapie ontvang gedurende hospilalisasie, maar slegs in die geval van die eksperimentele groep is met ouers beraadslaag en ' $n$ tuisbehandelingsprogram aangelers By vergelyking van hertoelatingssyfers vir die eksp. mentele en kon/rolegroepe, is 'n statisties betekenisvolle yerskil gevind by beide $5 \%$ en $1 \%$ vlakke, deur gebruik te maak van die chi-kwadraat toets.

sinus infection, or following a common cold. It may also exist in the lower respiratory tract following an infection of the trachea, or occurring as part of a generalized inflammation of the airways.

All of these disorders may be fatal if the parents do not understand the vital necessity of early treatment. If they receive sufficient counselling and advice to carry out an effective treatment during the stage of increased secretions, they can do much to prevent the progression of these disorders.

\section{REASONS FOR INSTITUTING A HOME TREATMENT PROGRAMME}

\section{Preventative care:}

- To prevent complications through early and effective treatment. Infants and young children are usually hospitalized as a result of the complications of the respiratory disorders, e.g. atelectasis and infection. These complications occur because it is difficult for the infant and young child to clear bronchial obstructions due to its hyperpobile thorax and underdeveloped muscular cons , With effective postural drainage such complícations can be prevented (Fig. 1) (Shepherd, 1974).

- To avoid the adverse psychological effects of hospitalization on the child. Children who suffer from disorders of the respiratory tract are often of an anxious nature. This anxiety is obviously increased in a strange hospital environment without the reassurance of the mother's presence.

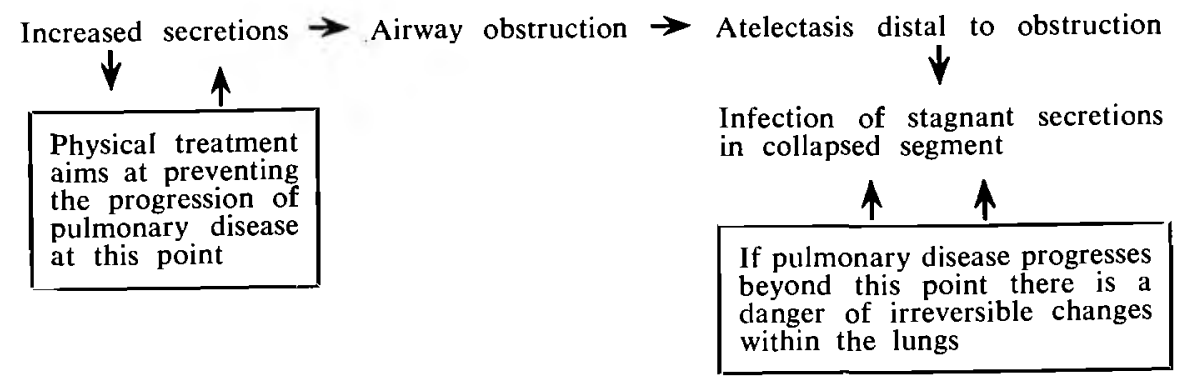


To educate the parents:

- To understand as far as possible and execute the various therapeutic manoeuvres. They can then play a role in helping to promote the normal functioning of the child and preventing further deterioration of the condition. Exercises must be simple yet effective.

- To learn and accept the limitations placed on the child by the handicap, so preventing them from demanding too much from the child.

- To understand the importance of continuing treatment at home.

- To recognise any deterioration in the child's condition so that early medical intervention can take place.

To fulfil the following psycho-dynamic or counselling tasks:

To help the parent accept the child emotionally and to adjust to its handicap. Rejection of the child will have a detrimental effect on the child's progress.

- To provide the parent with emotional support and reassurance, particularly when the progress is slow and the treatment is of a long-term nature.

- To reduce the parents' anxiety about the child and their fears for him/her being hurt when they help him.

- To instil in the parents a realistic sense of confidence concerning their child's future potential. Confidence felt by the parents is communicated to the child and is of profound value in motivating the child to participate fully in treatment.

- To motivate the parents to work diligently together with the child on the home treatment programme.

- To provide the parents with the opportunity to discuss freely any problems that they are experiencing with the child.

- To bring the parents to the realization that only a part of the child's treatment takes place in the hospital. The major part of the treatment regime must take place in the home.

To include the parents in the treatment team:

- Physiotherapists are often involved in their own little world of physiotherapy and fail to allow members of the patient's family to aid actively in the treatment régime. Provided that counselling is adequate, the parent will be motivated to treat the child effectively and will obtain great satisfaction from this.

To save valuable treatment time and unnecessary expense:

- It is sometimes impossible for the parents to bring the child to the out-patient department for regular treatment due to factors such as distance, transport problems, lack of money and lack of time (the mother is working), etc., so that it is essential for the child to receive treatment at home.

- The hospitalisation period of a long-term patient can be shortened considerably when the parent carries on with the treatment at home. At the time of writing (1978), the running cost of a teaching hospital bed was R53,78 per day. Hospital expenses can be kept to a minimum by reducing the hospitalisation period.

\section{METHOD}

Short-term patients (between the age of 1 month and 11 years) hospitalised for complications from their res-

piratory disorders and also those with chronic respiratory disorders were selected for the study. They were divided into an experimental and a control group. The experimental group received intensive physiotherapy treatment during their stay in hospital and the parents were educated as to an effective home treatment régime. The control group received intensive physiotherapy treatment during hospitalisation only.

The selection of the groups was done proportionally so that the two groups were equal and to prevent bias influencing the results. The advantage of selecting shortterm patients was that the greater part of the treatment would have to be on an out-patient basis or as a home treatment programme. Although the parents were seen only once or twice there was enough time to educate and assist them. Simple equipment such as that which they would have at home, i.e. chairs, blankets, etc., were used when demonstrating the treatment régime.

The treatment programme was standardized with emphasis on the most important techniques for each disorder. The parents were taught to use postural drainage, percussion and vibration techniques, breathing and coughing exercises, relaxation methods, "nose-drill" and general fitness exercises. General advice was also given.

Every patient was categorized according to age, disorder and date of hospitalisation. After a period of 3 months (May to July 1978) a follow-up study was done to determine the frequency of re-admittance to hospital.

\section{RESULTS}

The number of children re-admitted to hospital for the same condition or a complication thereof, was recorded (Fig. 2). "Frequency" indicates the number of times readmitted, "children" the number of children re-admitted.

Experimental group

(those with a home

treatment programme)

$\begin{array}{cc}\text { Frequency } & \text { Children } \\ 0 & 23 \\ 1 & 4 \\ 2 & 1 \\ 3 & 1 \\ 4 & 1 \\ 5 & 0 \\ \text { Total } & 30\end{array}$

Control group (those without a home treatment programme)

\begin{tabular}{cc}
\hline Frequency & Children \\
0 & 8 \\
1 & 10 \\
2 & 8 \\
3 & 1 \\
4 & 2 \\
5 & 1 \\
Total & 30
\end{tabular}

Fig. 2

Before the experiment was started the following hypothesis was propagated: "There is no difference between the experimental and the control group". If this hypothesis proved incorrect, the assumption could be made that home treatment programmes were a success. The chi-square test was used to compare the two groups and the theoretical distribution depended on the assumption that the frequency of re-admittance was coincidental and that there was no difference whatsoever between the two groups of patients.

The acquired $\chi^{2}>$ critical $\chi^{2}$ at both the $5 \%$ and $1 \%$ levels. (Fig. 3.)

The negative hypothesis was therefore not acceptable and a significant difference between the two groups was evident. The percentage of children re-admitted to hospital was $23,3 \%$ in the case of the experimental group and $73,3 \%$ in the case of the control group.

\section{CONCLUSION}

A home treatment programme could be of great benefit to everyone involved. The child could be saved 


\begin{tabular}{|c|c|c|c|c|c|c|c|}
\hline & Class & $f$ & $f^{1}$ & $f-f^{1}$ & $\left(f-f^{2}\right)^{2}$ & $\frac{\left(f-f^{1}\right)^{2}}{f^{1}}$ & \multirow{4}{*}{$\begin{array}{c}f=\begin{array}{l}\text { actual frequency of } \\
\text { re-admittance }\end{array} \\
f^{1}=\begin{array}{l}\text { theoretical frequency } \\
\text { of re-admittance }\end{array}\end{array}$} \\
\hline $\begin{array}{l}\text { Experimental } \\
\text { group }\end{array}$ & $\begin{array}{c}0 \\
1-2 \\
3+\end{array}$ & $\begin{array}{r}23 \\
5 \\
2 \\
\end{array}$ & $\begin{array}{c}15,5 \\
11,5 \\
3\end{array}$ & $\begin{aligned} & 7,5 \\
&-6,5 \\
&-1\end{aligned}$ & $\begin{array}{c}56,25 \\
42,25 \\
1 \\
\end{array}$ & $\begin{array}{l}3,63 \\
3,68 \\
0,33 \\
\end{array}$ & \\
\hline \multirow[t]{2}{*}{$\begin{array}{l}\text { Control } \\
\text { group }\end{array}$} & $\begin{array}{c}0 \\
1-2 \\
3+\end{array}$ & $\begin{array}{r}8 \\
18 \\
4\end{array}$ & $\begin{array}{c}15,5 \\
11,5 \\
3\end{array}$ & $\begin{array}{c}-7,5 \\
6,5 \\
1\end{array}$ & $\begin{array}{c}56,25 \\
42,25 \\
1\end{array}$ & $\begin{array}{l}3,63 \\
3,68 \\
0,33\end{array}$ & \\
\hline & & $=60$ & $f^{\prime}=60$ & & \multicolumn{2}{|c|}{$\chi^{2}=15,28$} & \\
\hline
\end{tabular}

$x^{2}=15,28$ (acquired chi-square)

Degrees of freedom $=2$.

Critical $\chi^{2}: 5 \%$ level $=5,991$.

$1 \%$ level $=9,210$.

Fig. 3

from unnecessary psychological and physical trauma during recurrent periods of hospitalisation and the family will be spared unnecessary expense. Every physiotherapist should therefore motivate the parent of such a child to become a member of the team.

\section{References}

1. Burgess, J. (1965). The management of sick children in hospital from the physiotherapist point of view. Physiother., 51. 183 - 186.

2. Goldin, C. J. (1965). The physical therapist as parent counsellor: an emerging role. Phys. Ther., 45, 67.

3. Hooson, E. P. G. (1961). Physical therapy in relation to the disabled patient and the home. Physiother., 47, $133-135$.

4. Porter, A. L. (1967). Physiotherapy in the treatment of bronchiolitis and bronchopneumonia in babies and young children. Physiother., 53. $333-335$.

5. Reynolds, R. J. S. (1975). Paediatric physiotherapy in the past 25 years. Physiother., 61, 106-108.

6. Shepherd, R. (1974). Physiotherapy in Paediatrics. A!den and Mowbray. Oxford. 